\title{
Mikroskopia trójwymiarowych struktur komórkowych - od mikroskopu świetlnego do konfokalnego
}

\author{
Izabela Łaska \\ Uniwersytet Gdański, Wydziat Biologii \\ E-mail: izabelalaska1998@gmail.com \\ tutor: dr hab. Agnieszka Kowalkowska, prof. UG \\ Uniwersytet Gdański, Wydziat Biologii, Katedra Cytologii i Embriologii Roślin
}

Słowa kluczowe: mikroskopia świetlna i konfokalna, neurony, obrazy trójwymiarowe, układ nerwowy

\section{Wstęp}

Od czasu pracy Golgiego i Cajala (1903) mikroskopia pozostaje kluczowym narzędziem dla neuronaukowców chcących obserwować komórki nerwowe (Grant, 2007). Podstawową i najpowszechniejszą techniką mikroskopową w dalszym ciągu pozostaje mikroskopia świetlna i od niej wszystko się zaczęło. Pierwsze mikroskopy konstruowano już w XVI wieku (Trzaskoma i Magalska, 2019). Współczesne mikroskopy to urządzenia o wysokim stopniu automatyzacji, zintegrowane z komputerem i kamerą cyfrową. Ciągłe postępy otworzyły nowe możliwości eksperymentalne do badania układu nerwowego w wielu skalach przestrzennych. Nowatorskim rozwiązaniem w mikroskopii świetlnej są mikroskopy konfokalne, w których do skanowania próbki wykorzystana jest wiązka światła laserowego. W swojej pracy dokonałam przeglądu technik wizualizacji komórek, które mogą być szczególnie interesujące dla neuronaukowców.

\section{Początki badań mikroświata}

Pod koniec XVI wieku holenderscy producenci soczewek Janssen i Lipperhey konstruowali aparaty umożliwiające powiększanie obiektów, natomiast już w 1609 roku Galileo Galilei skonstruował pierwsze narzędzie noszące miano mikroskopu. Słowo mikroskop jest kombinacją dwóch greckich wyrazów - micros, oznaczającego mały, i skopeo - obserwuję. Zatem łącznie oznacza to "obserwuję małe rzeczy" (Bąbel, 2014).

Wynalazek mikroskopu konfokalnego przypisuje się Marvinowi Minsky'emu, który początkowo w 1955 roku wykorzystał skaningowy mikroskop optyczny w celu obrazowania sieci neuronowych żywej tkanki mózgowej w preparatach nieutrwalonych. Utrudnieniem, jakie napotkał Minsky pod- 
czas zastosowania mikroskopu optycznego, był brak rozdzielczości przestrzennej w trójwymiarowych strukturach skrawków badanego materiału (Korczyński i in., 2013).

Bazując na swoich obserwacjach w 1961 roku zbudował pierwszy, skanujący mikroskop konfokalny. W oryginalnym mikroskopie konfokalnym Minsky'ego punktowe źródło światła jest wytwarzane przez cyrkonową lampę łukową. Światło pochodzące z preparatu było następnie zbierane przez obiektyw znajdujący się po drugiej stronie próbki. Aby utworzyć obraz całego preparatu, pierwszy mikroskop konfokalny był wyposażony w ruchomy stolik, który przesuwając się umożliwiał oświetlanie kolejnych punktów na badanym materiale. Używając dwóch elektromagnesów do przesuwania stolika mikroskopowego w osiach $X$ i $Y$ oraz specjalnego oprogramowania komputerowego do składania obrazu. Minsky był w stanie uzyskać obraz jednego przekroju optycznego preparatu w czasie 10 sekund (Minsky, 1988). Obrazy wyprodukowane przez instrument Minsky'ego w tym czasie pozostały jednak niedocenione. Uważam, że warto zwrócić uwage na fakt, iż technologia mu dostępna w 1955 roku nie była wystarczająca, aby w pełni zademonstrować potencjał konfokalny. W tym czasie biolodzy byli przyzwyczajeni do oglądania i fotografowania jasno zabarwionych i kolorowych skrawków tkanek histologicznych analizowanych za pomocą mikroskopów świetlnych o doskonałej optyce. W oryginalnym projekcie Minsky'ego niezwykle trudno było zlokalizować interesujący nas region w preparacie oraz ustawić ostrość. Jednak nie ulega wątpliwości, że był to przełomowy wynalazek zmieniający bieg historii w mikroskopii trójwymiarowych struktur. Konfokalne obrazowanie żywych tkanek na czas popularności musiało poczekać aż do 1979 roku, kiedy to Fred Brakenhoff opatentował konstrukcję skanującego mikroskopu konfokalnego. Brakenhoff jako źródło światła wykorzystał laser. Powyżej zaprezentowane odkrycia bezpośrednio przyczyniły się do zapoczątkowania wielu nowych technik, których zastosowanie umożliwił skanujący, laserowy mikroskop konfokalny. W Polsce w 2002 roku powstała Pracownia Mikroskopii Konfokalnej w Instytucie Biologii Doświadczalnej im. Marcelego Nenckiego w Warszawie jako laboratorium środowiskowe. W ramach działań badawczych laboratorium dysponuje szerokim wachlarzem metod, zarówno z zakresu biologii komórki (mikroskopia konfokalna i elektronowa), jak również biologii molekularnej i biochemii. Przedmiotem ich badań są układy o różnym stopniu złożoności zarówno w aspekcie morfologicznym, jak i funkcjonalnym - całe organizmy, tkanki, komórki, organelle komórkowe, ale także białka i geny. Jednostka zajmuje się badaniem neuronów głębokich warstw korowych mózgu u zwierząt doświadczalnych (Korczyński, 2013). Aktualnie Instytut Nenckiego jako jedyna placówka naukowa w Polsce realizuje badania w zakresie neuronauki na wszystkich poziomach - od molekularnego do systemowego [1].

\section{Mikroskopia STED - szczegółowe prześwietlenie żywych komórek}

Podczas leczenia chorób, bardzo istotne jest przyjrzenie się im uważnie na poziomie molekularnym. Zachodzą bowiem procesy, które odróżniają zdrowe komórki od chorych. Do niedawna naukowcy nie byli w stanie badać tych procesów w żywych komórkach, ponieważ konwencjonalne mikroskopy świetlne nie zapewniały niezbędnej rozdzielczości. Zmieniło się to jednak wraz z wynalezieniem mikroskopu STED. Dzięki mikroskopowi STED naukowcy mogą teraz nawet dziesięć razy ostrzej obserwować pojedyncze cząsteczki w żywych komórkach: szczegółowo skanują komórki nerwo- 
we, przesiewają wirus HIV, a nawet zaglądają do mózgu żywych myszy. Innymi słowy, średnica wiązki światła nie może być mniejsza niż 200 nanometrów. Najmniejszy punkt, który można sfotografować, to ten rozmiar. Struktury komórkowe lub cząsteczki, które są mniejsze, wydają się niewyraźne. Dzięki mikroskopii elektronowej detale mniejsze niż 200 nanometrów mogą być rozdzielone przez długi czas, ale to niszczy struktury komórkowe i nie może być stosowane w żywych organizmach. W 1994 roku Stefan Hell i Jan Wichmann po raz pierwszy opisali teoretycznie zasadę mikroskopii STED (ang. stimulated emission depletion), co tłumaczy się jako "stymulowane wygaszenie emisji". Dokładnie 20 lat później Hell otrzymał Nagrodę Nobla w dziedzinie chemii za swoje osiągnięcia wraz z amerykańskimi badaczami Eric'em Betzig z Instytutu Medycznego Howarda Hughesa i Williamem Moerner z Uniwersytetu Stanforda. Hell mówi, że metoda jest daleka od wyczerpania oraz posiada aktualnie bardzo małe ograniczenia co do cząsteczki. Natomiast w 2012 roku wraz z naukowcami z Instytutu Chemii Biofizycznej im. Maxa Plancka przyjrzeli się bezpośrednio mózgo-
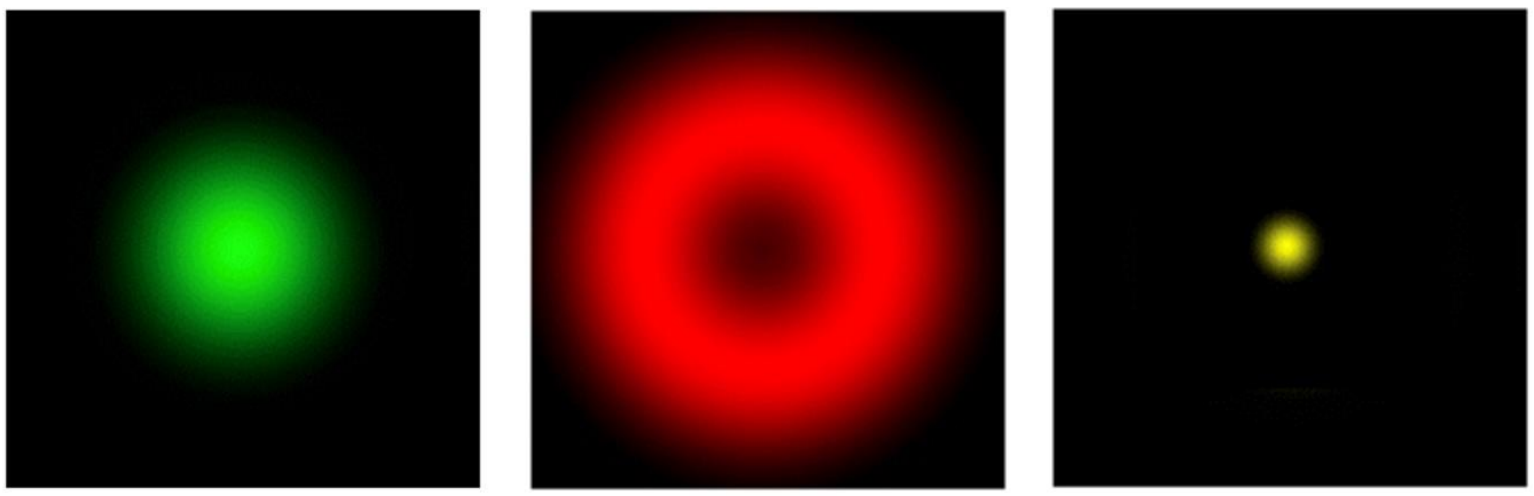

Ryc. 1. Ograniczone dyfrakcyjne wzbudzenie z lasera Superk (po lewej), ubytek w kształcie zbliżonym do pączka z lasera Katana-HP (centrum), super-rozdzielczy sygnał fluorescencji po wyczerpaniu (po prawej) [2]

Nowy „NEUROwymiar" mikroskopii

Skanujący laserowy mikroskop konfokalny jest niezbędny i nieoceniony jako narzędzie wi żywych myszy za pomocą mikroskopu STED. Zeskanowali komórki nerwowe z górnej warstwy mózgu gryzonia z niespotykaną dotąd szczegółowością. Ujawniło to coś zaskakującego: elementarne punkty styku obwodu mózgu, wyrostki kolczyste komórek nerwowych, mogą pozornie poruszać się i zmieniać swój kształt. „W przyszłości bardzo ostre nagrania na żywo mogą nawet pokazać, jak pewne białka są rozmieszczone w synapsach" - powiedział Hell. Dzięki takim coraz bardziej szczegółowym obrazom naukowcy mają nadzieję lepiej zrozumieć choroby, takie jak autyzm czy epilepsję, ponieważ są one oparte na wadliwym działaniu synaps. Mikroskopia STED jest szeroko stosowana do badania próbek luminescencyjnych o wysokiej rozdzielczości przestrzennej znacznie poniżej bariery dyfrakcyjnej w biologii i medycynie. Dlatego w konfokalnym laserowym mikroskopie skaningowym próbkę wzbudza się za pomocą lasera impulsowego o ograniczonej dyfrakcji, a następnie drugiego impulsu laserowego w kształcie pierścienia, który jest przesunięty ku czerwieni względem widma emisyjnego chromoforu (Ryc. 1). 


\section{Tutoring Gedanensis}

paratów (utrwalonych lub żywych). Tworzenie takich przekrojów pozwala na znacznie dokładniejszą niż dotychczas obserwację struktury analizowanej próbki, jak i uzyskanie obrazów w postaci trójwymiarowej (3D) rekonstrukcji. Obrazy standardowo są zbierane $w$ trybie poklatkowym. Zbieranie obrazów odbywa się w ustalonych odstępach czasu inastępnie są one umieszczane w pliku, który jest zwykle oglądany jako film. Poczyniło to znaczne postępy o wyobrażeniu życia komórki nerwowej lub morfologii komórek glejowych. Przy obrazowaniu żywych komórek należy zachować szczególną ostrożność, aby zachować żywotność komórek na etapie mikroskopu. W związku z tym podczas procesu obrazowania należy używać minimalnych mocy lasera, ponieważ są one szkodliwe. Większość nowoczesnych systemów konfokalnych została znacznie ulepszona w porównaniu z wcześniejszymi modelami, a także w połączeniu z wysoką przepustowością soczewki i jaśniejszymi, mniej fototoksycznymi barwnikami, te ulepszenia sprawiły, że analiza konfokalna żywych komórek stała się wyjątkowo praktyczną opcją. Na uwagę zasługuje fakt, że w efekcie rozwoju mikroskopii konfokalnej powstała międzynarodowa baza NeuroMorpho.Org. Jest to ogólnodostępny spis neuronów zrekonstruowanych cyfrowo, który współpracuje z ponad 500 laboratoriami na całym świecie. Do zalet laserowego mikroskopu konfokalnego należy zastosowanie koherentnego światła laserowego, które umożliwia wybiórcze wzbudzanie fluorescencji poszczególnych substancji, oraz możliwości rekonstrukcji wyraźnego obrazu z całej objętości szkiełka, na poziomie komórkowym (Ryc. 2) (RomanowskaPawliczek, 2010).

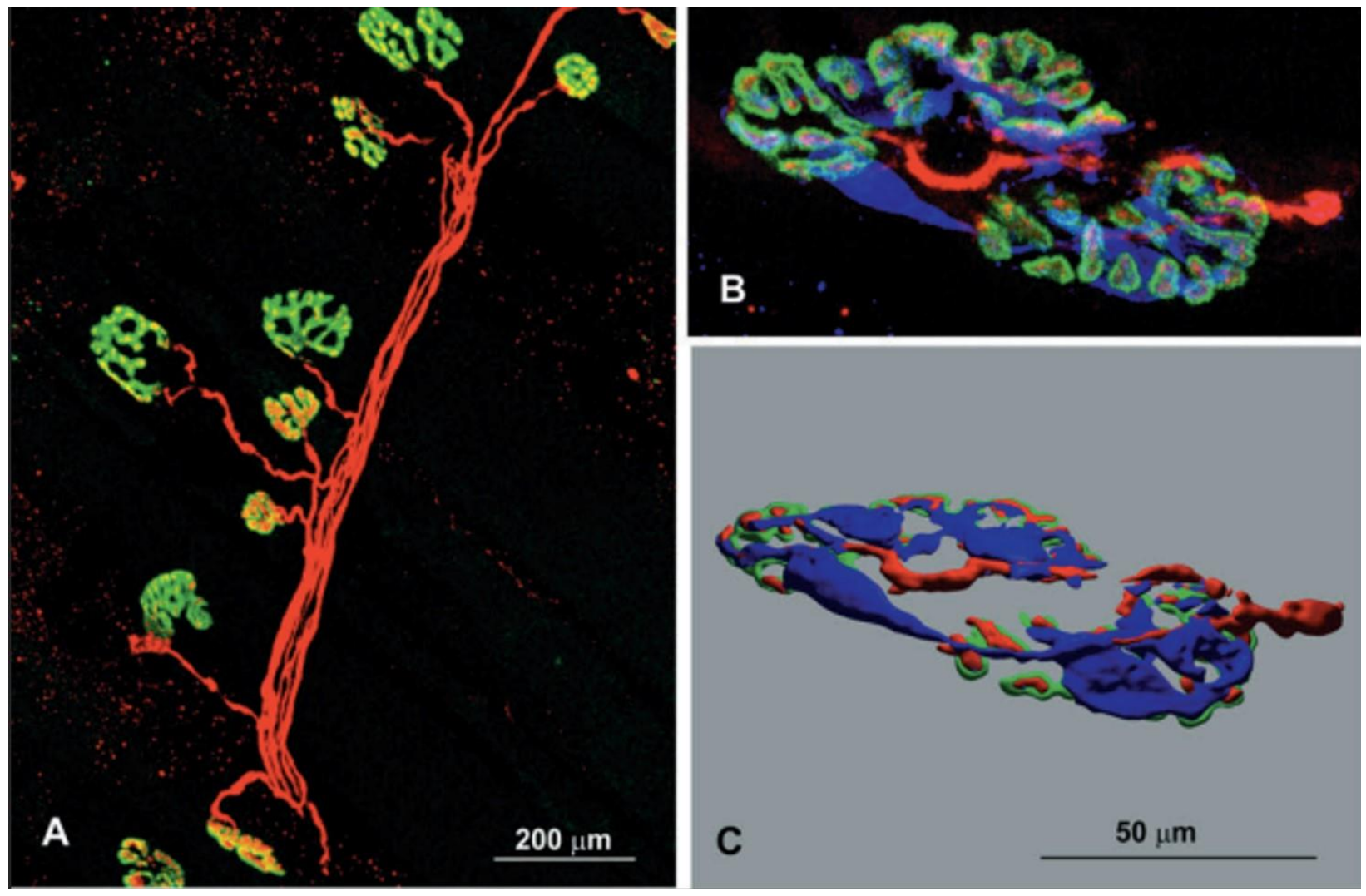

Ryc. 2. A-C Obraz synaps nerwowo-mięśniowych szczura w mikroskopie konfokalnym, w małym (A) i dużym powiększeniu (B-C). Kolor czerwony - znacznik włókien nerwowych, kolor zielony - znacznik receptorów acetylocholinowych, kolor niebieski - znacznik komórek glejowych [3] 


\section{Czy 3D zdominowało obrazowanie?}

Chociaż minęło ponad 100 lat od otrzymania Nagrody Nobla przez Santiago Ramón y Cajala za opracowanie "doktryny neuronów", wciąż brakuje nam informacji opisujących strukturę 3D sieci neuronalnych. Do dzisiaj to pozostaje wyzwaniem oraz jest głównym celem neuronauki, aby zrozumieć związek między złożonością architektury mózgu, która wymaga pomiarów tkanki bazujących na obrazie, a jego funkcjonalnością w układzie nerwowym. Charakterystyka i zrozumienie morfologii neuronów są fundamentalnie ważne dla wyjaśnienia zakresu różnorodności neuronalnej. Na podstawie literatury można wywnioskować, że światowe inicjatywy neurobiologiczne są nastawione właśnie na zrozumienie różnorodności typów komórek nerwowych, jako krok w kierunku wyjaśnienia związku między strukturą czy morfologią neuronów a ich funkcją. Jest to możliwe dzięki obrazowaniu za pomocą mikroskopii konfokalnej, która umożliwia uzyskanie wysokiej jakości obrazów oraz ich konstrukcji w 3D (Jacob, 1990). Obrazowanie trójwymiarowe jest zdecydowanie korzystniejsze niż dwuwymiarowe, ponieważ dostarcza dokładniejszych informacji na temat badanej struktury. Jednakże to obrazowanie wymaga uzupełniającej mocy komputerowej, zwłaszcza dla wyeksponowania i interpretacji struktury. Neurony mają postać drzew aksonalnych i dendrytycznych. Ich nadrzędnym elementem jest cylindryczne odgałęzienie. Ponadto w przypadkach, gdy neurony posiadają płaską strukturę, jak np. komórki zwojowe siatków$\mathrm{ki}$, to ich ujęcie 3D umożliwia dokonanie rozdziału skrzyżowań cienkich segmentów (Turner i in., 1999).

Zaletą mikroskopu konfokalnego jest dokładna wizualizacja preparatów w osiach X, Y oraz Z. Obraz powstały w ten sposób pozwala na tworzenie trójwymiarowej rekonstrukcji badanej próbki przy użyciu takich programów jak Imaris czy Image Pro Plus. Powstałe rekonstrukcje mogą zostać poddane procesowi dekonwolucji w programach Huygens lub AutoQuant, który eliminuje zakłócenia obrazu wywołane fizycznymi ograniczeniami optyki mikroskopowej, w ten sposób stają się niemal rzeczywistym odzwierciedleniem badanych mikroskopijnych obiektów. Warto w tym miejscu dodać, że mikroskop Leica TCS SP5 jest wyposażony $w$ innowacyjny moduł STED umożliwiający obrazowanie z rozdzielczością w osiach XY poniżej $90 \mathrm{~nm}$, a zatem ponad dwa razy większą niż w konwencjonalnych mikroskopach konfokalnych. Pozwala to na dokładniejszą analizę preparatów barwionych fluorescencyjnie, m.in. szczegółowe pomiary kształtu i lokalizacji wybarwionych struktur, a tym samym bardziej precyzyjne określenie ich kolokalizacji w preparacie (Ryc. 3). Natomiast z drugiej strony, przy badaniu dużych obiektów biologicznych, mikroskop Leica, dzięki zastosowaniu zmotoryzowanego stolika, pozwala wykonać i połączyć ze sobą w jedną całość obrazy z sąsiadujących ze sobą pól widzenia (Korczyński i in., 2013). Pamiętajmy jednak, że nie wszystkie typy mikroskopii mogą być wykorzystane w trójwymiarowym obrazowaniu, w związku z tym obrazowanie dwuwymiarowe w neurobiologii pozostanie cenne na długo.

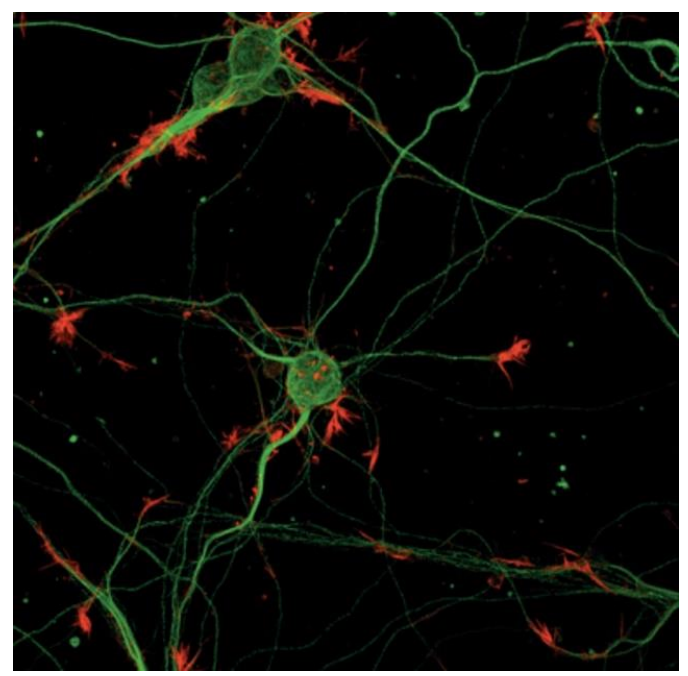

Ryc. 3. Neurony korowe myszy z wybarwionymi filamentami aktynowymi w stożkach wzrostu [4] 


\section{Podsumowanie}

Ostatnie kilka lat było wyjątkowo owocne dla rozwoju nowej mikroskopii. Nie ulega wątpliwości, że mikroskop konfokalny posiada przewagę w obrazowaniu komórek mózgowych nad konwencjonalnym mikroskopem optycznym, ponieważ umożliwia cięcie i tworzenie trójwymiarowych (3D) obrazów. Ze względu na tę wyjątkową cechę mikroskop konfokalny znajduje obecnie szerokie zastosowanie w badaniach. W powyższej pracy starałam się podkreślić wyjątkowe zalety mikroskopii konfokalnej płynące z przełomowych badań ostatnich dekad w celu lepszego zrozumienia mikrostruktury neuronalnej i towarzyszących im mechanizmów różnych ważnych neurozjawisk.

\section{Literatura:}

Bąbel, A., 2014. Świat w powiększeniu. Dziewiętnastowieczny mikroskop jako instrument i jako metafora, Wydawnictwo Instytut Badań Literackich PAN, s. 108-122.

Grant, G., 2007. How the 1906 Nobel Prize in Physiology or Medicine was shared between Golgi and Cajal. Brain Research Reviews, 55 (2), 490-498. DOI: 10.1016/j.brainresrev.2006.11.004

Jacob, R., Glaser, E., Glaser. M., 1990. Neuron imaging with neurolucida-a PC-based system for image combining microscopy. Computerized Medical Imaging and Graphics, 14 (5), 307-317.

Korczyński, J., 2013. Nowy wymiar mikroskopii skanujący laserowy mikroskop konfokalny. Kosmos, 62 (2), $149-160$.

Kuźnicki, L., Sikora, J., Wyroba, E., Jakubiec-Puka, A., Pomorski, P., Wasik, A., JerkaDziadosz, M., Wilczyński, G., Kasprzak, A., Kamińska, B., Zawadzka, M., Szydłowska, K., Ellert- Miklaszewska, A., Gabrusiewicz, K., Sielska, M., Korczyński, J., Kłopocka, W., Piwocka, K., Szczepa- nowska, J., 2013. Mikroskopia i obrazowanie, Wydawnictwo Retro-Art, s. 7183.

Minsky, M., 1988. Memoir on inventing the confocal scanning microscope. Scanning, 10, 128-138.

Romanowska-Pawliczek, A., 2010. Rekonstrukcja 3D komórek glejowych mózgu, Kraków, Akademia Górniczo-Hutnicza, 23-24.

Trzaskoma, P., Magalska, A., 2019. Nowoczesne techniki mikroskopowe w badaniach nad trójwymiarową strukturą chromatyny. Kosmos, 68 (1), 19-33.

Turner, J.N., Shain, W., Szarowski, D.H., Lasek, S., Sipple, B., Pace, C., Al-Kofahi, K., Can, A., Roysam, B., 1999. Confocal light microscopy of brain cells and tissue: image analysis \& quantitation, Acta Histochemica et Cytochemica, 32 (1), 5-11.

\section{Źródła internetowe:}

[1] Instytut Biologii Doświadczalnej im. Marcelego Nenckiego, 2021.

http://www.nencki.gov.pl/ [Dostęp z dnia 28.07.2021]

[2] NKT Photonics, 2020. https://www.nktphotonics.com/ [Dostęp z dnia 10.07.2021]

[3] http://rcin.org.pl/Content/33519/WA488_523 14_19300_Mikroskopia.pdf, [Dostęp z dnia 29.05.2021]

[4] http://rcin.org.pl/Content/33519/WA488_523 14_19300_Mikroskopia.pdf/, [Dostęp z dnia 10.05.2021]

Notka o Autorce: Studentka III roku studiów I stopnia na kierunku Biologia Medyczna Uniwersytetu Gdańskiego. Jej głównym obszarem zainteresowań jest neuroobrazowanie pozwalające na badanie procesów mózgowych oraz fizjologia snu w perspektywie neuroobrazowania, z tego też względu jako specjalność wybrała Neurobiologię. Esej powstał jako efekt pracy po ćwiczeniach warsztatowych „Współczesne problemy naukowe w biologii - tutoring naukowy". 